\title{
Seed germination conditions and implications for establishment of an epiphyte, Aechmea bracteata (Bromeliaceae)
}

\author{
Laurel K. Goode $\cdot$ Michael F. Allen
}

Received: 7 November 2008/Accepted: 13 January 2009/Published online: 29 January 2009

(C) The Author(s) 2009. This article is published with open access at Springerlink.com

\begin{abstract}
Aechmea bracteata is a common epiphytic bromeliad found in symbiosis with many other species throughout tropical forests of Mexico and south through Panama. Given its importance and distribution in these forests, we asked how may A. bracteata be restored to areas where they have thrived in the past? We first investigated seed viability and response of seed germination to temperature, humidity, vapour pressure deficit (VPD), and light, under controlled growth chamber conditions. We recorded these environmental conditions within a seasonal tropical forest where this species is common and then conducted seed germination trials in various seral stages. In growth chambers, with constant water supply, highest germination percentages were at the highest temperature and lowest VPD levels. In the field, germination was less than $1 \%$. Because of high temperatures and VPD within early seral stages, efforts to re-introduce A. bracteata into forests $<20$ years old are not likely to be successful.
\end{abstract}

Keywords Aechmea bracteata .

Environmental conditions · Epiphyte .

Germination $\cdot$ Mexico $\cdot$ Restoration

L. K. Goode $(\varangle) \cdot$ M. F. Allen

Center for Conservation Biology, Department of Biology,

Webber Hall, University of California, Riverside,

Riverside, CA 92521, USA

e-mail: 1salz001@ucr.edu

\section{Introduction}

Plant establishment depends upon successful dispersal into a suitable habitat and the ability to survive in interaction with the surrounding environment and neighboring biota (Schupp 1995; Lambers et al. 1998). Seedling establishment is often the life stage where plants are most vulnerable (Harper 1977; Mondragon et al. 1999; Rey and Alcántara 2000; Toledo-Aceves and Wolf 2008). The epiphytic bromeliad, Aechmea bracteata (SW.) Griseb has a distribution that ranges from Central Mexico south throughout Central America and including Caribbean islands (Missouri Botanical Garden, http://www. mobot.org/). Throughout its range, A. bracteata is found in low densities in both lowland inundated forests and upland semideciduous forests. However, it is more than twice as common in seasonally inundated forest types (Dejean and Olmstead 1997). In contrast to late-seral forests and dense secondary vegetation, these mature wetland forests are characterized by short-statured and open vegetation (Schultz 2001). Dominated by the species Haematoxylum campechianum L., known locally as the tinta tree, these wetland forests are referred to as "tintal" wetlands. Because of seasonal flooding, this vegetation is less susceptible to burning and often is older than surrounding forest. However, A. bracteata are not found in recently disturbed patches in the region. A combination of factors including differing abiotic conditions, physiological constraints, and biotic interactions could influence the 
distribution of this species. We investigated the effect of habitat variability on seed germination and seedling establishment of A. bracteata.

A. bracteata utilizes crassulacean acid metabolism (CAM), a water conserving mode of photosynthesis that contributes to slow growth, but may also "enhance stress tolerance and recovery" (Ehleringer and Monson 1993). Larger, well-developed plants have both a central, water-impounding tank and water-tight dry chambers suitable for housing ants (Benzing et al. 1972; Benzing 2000). However, as seedlings and young juvenile plants, the tanks are not yet developed for water storage, so periods with little to no water are likely to affect these young plants more severely than older con-specifics (Hietz and Wanek 2003). As a tank bromeliad, A. bracteata is tightly linked to other organisms in suitable habitats. Richardson et al. (2000) found tank bromeliads in Puerto Rico to be important contributors to the food chain, calculating a provision of up to 65,000 food items per hectare from bromeliad tanks. Large specimens of $A$. bracteata have central tanks that can contain up to $200 \mathrm{ml}$ of water and may have 10 or more outer chambers that are also capable of water storage (Benzing et al. 1972; Dejean and Olmstead 1997). In addition to its role in water storage and cycling, A. bracteata is frequently associated with ants (Dejean et al. 1995, 2003) and frogs (Galindo-Leal et al. 2003).

Tropical ecosystems, including those where these plants are found, are under increasing threat from encroaching human activity. In the last 50 years, rates of deforestation increased while human populations in the tropics more than doubled (Wright 2005). Wright and Muller-Landau (2006) argue that as population growth rates begin to decrease so will rates of deforestation. Currently, secondary forests cover more area than mature forests (Chazdon 2003), and previous land use affects future species composition (Svenning et al. 2004). Land use change directly impacts native vegetation, and low-intensity escaped agricultural fires or natural fires have indirect effects by changing the canopy structure (e.g., leaf loss, increased canopy openness) (Robertson and Platt 1992). Epiphytes directly influence abiotic conditions (e.g., temperature and humidity) (Stuntz et al. 2002), so removal (e.g., as a land management practice for coffee production) or disturbance (such as epiphyte removal by wind, Goode and Allen 2008) will result in a cascade of effects on other organisms.
Efforts to restore epiphytes, specifically a tank bromeliad such as A. bracteata, to ecosystems where they have been denuded face many challenges. An understanding of the physiological limits of the biota being restored is critical to a re-introduction and successful establishment of the species. Temperature, humidity, vapour pressure deficit (VPD), precipitation, light, and atmospheric $\mathrm{CO}_{2}$ concentration must be within favorable ranges, as well as the presence of suitable host species. The objective of this study was to provide insight into what age forests epiphytes, specifically A. bracteata, may be re-introduced, and this study was designed to directly address the question of whether or not young forests $(<20$ years old) house environmental conditions (temperature, humidity, and VPD gradients) favorable for epiphyte establishment. Our main research questions were: (1) what are the temperature, humidity, and VPD optima for germination of $A$. bracteata seeds, and how long are seeds viable, (2) how do temperature, humidity, and VPD vary among different forest stands of known age, and (3) are epiphyte germination and survival related to age of forest?

Our hypotheses were: (I) Seeds in the field trials would germinate and be successful only in the welldeveloped forests types, with greater than 50 years of stand development. A. bracteata are not typically found in young secondary forests or restoration areas. (II) Seeds in the growth chamber trials would be viable for less than 1 year. Epiphyte seeds in tropical forests are not protected by buffering of soil and are subject to seed predation. (III) Light would not be a critical factor for seed germination. Non-dormant seeds have been shown to germinate equally in both light and dark conditions (Baskin and Baskin 1998). (IV) Germination in growth chambers would be the highest when conditions were in the range of those typical of mature forest and wetland areas, as $A$. bracteata are commonly found in these ecosystems (Dejean and Olmsted 1997; Goode and Allen 2008).

\section{Materials and methods}

\section{Study area}

El Edén Ecological Reserve, an education and research reserve in northwest Quintana Roo, Mexico, was utilized for this study because mature A. bracteata are 
found in abundance throughout the reserve, especially in the tintal wetland area and the mature forest. The site was optimal for this study, located on a flat, limestone bedrock with shallow $(<10 \mathrm{~cm})$ highly organic soil. The mature forest supports a canopy less than $20 \mathrm{~m}$ in height and is adjacent to a wetland area with vegetation that is also greater than 100 years old (Gómez-Pompa et al. 2003). Across the site are a series of younger forests where fires have occurred in recent decades (Vargas et al. 2008). The dates of the burns are known. Two of these fires (one in 1989; one is 1999) burned the vegetation down to the limestone bedrock. The vegetation in these seral stages is now 19 and 9 years old, with a maximum height of $8 \mathrm{~m}$. Adjacent to the wetland area on the opposite side of the mature forest is a young forest where a fire had occurred in 1995. This fire burned less intensely than the other two, and some remnant trees are much older than the rest of the 13-year-old vegetation. An epiphyte community is present on these trees. For convenience, we designate these secondary forests as SF1 (19 years old), SF2 (13 years old), and SF3 (9 years old) per Goode and Allen (2008). The vegetation of El Edén is $96.5 \%$ native, with ca. 10\% of species present endemic to the Yucatán Peninsula (Schultz 2005). Additional details on the composition and structure of the vegetation are available (Schultz 2001, 2003, 2005; Vargas et al. 2008).

The reserve is a seasonally dry tropical forest because there is a significant dry period with a little to no rain (December through May). During this time the deciduous vegetation drops most of its leaves. Rainfall in the reserve averages $1,500-2,000 \mathrm{~mm} /$ year, mostly during the wet season which can be influenced by hurricanes such as Hurricane Wilma in October of 2005 (Goode and Allen 2008). Across the Yucatán Peninsula, hurricane activity has contributed to a higher percentage of rainfall over the last 50 years, due to an increase in the number and strength of the storms (Boose et al. 2003).

\section{Seed growth chamber trials}

Fruits were collected in August 2005, 2006, and 2007, and seeds were pooled for each year from $>5$ plants. These were used for growth chamber germination trials that began in September 2006. Seeds were subject to humidity/VPD, temperature, light, and viability trials. Only fresh seeds were used for all but the viability trials. A minimum of fifty seeds per replicate and three replicates were completed for each trial and treatment.

For the humidity/VPD trials, seeds were germinated on sterile filter paper in open individual petri dishes at $50 \%, 70 \%$, or $90 \%$ relative humidity $(\mathrm{RH})$ and were observed daily until $100 \%$ germination was reached or remaining seeds failed to germinate. Seeds were manually sprayed each day with deionized water, and the filter paper generally dried before the next watering event. In some cases, filter paper at $90 \% \mathrm{RH}$ remained damp for $>24 \mathrm{~h}$. No additional water was provided when this occurred. Germination was recorded at the first emergence of the radicle. The humidity trials were run with $12 \mathrm{~h}$ days at 28/ $24^{\circ} \mathrm{C}$ day/night temperature regime. VPD in the growth chamber ranged from $0.30 \mathrm{kPa}$ in the $90 \%$ $\mathrm{RH}$ treatment to $1.88 \mathrm{kPa}$ in the $50 \% \mathrm{RH}$ treatment (Table 1). The VPD treatments were calculated as the average of day and night values. The VPD gradient ranged from 1.68 to 1.01 to $0.34 \mathrm{kPa}$ for the three treatments. Temperature germination trials utilized three different temperature regimes: $28 / 24,24 / 20$, or 20/16 ( ${ }^{\circ} \mathrm{C}$ day/night temperatures, $12 \mathrm{~h}$ days, $70 \%$ $\mathrm{RH}$, Table 1). Additional trials were run with different light conditions. 'Shade' versus 'sun' conditions were simulated to see if this would have an effect on A. bracteata germination. A wooden frame was constructed and covered with shade cloth to create a fully shaded environment within half of a growth chamber. The shaded condition averaged $\sim 40 \mu \mathrm{mol} /$ $\mathrm{m}^{2} \mathrm{~s}$, one-tenth of the intensity of regular lighting at the bottom of the chamber $\left(\sim 400 \mu \mathrm{mol} / \mathrm{m}^{2} \mathrm{~s}\right)$.

Table 1 Growth chamber treatment conditions for seed germination

\begin{tabular}{lllllll}
\hline Treatments & RH $(\%)$ & \multicolumn{2}{c}{$T\left({ }^{\circ} \mathrm{C}\right)$} & & \multicolumn{2}{c}{ VPD $(\mathrm{kPa})$} \\
\cline { 7 - 8 } \cline { 6 - 7 } & & Day & Night & & Day & Night \\
\hline RH1 & 90 & 28 & 24 & & 0.38 & 0.30 \\
RH2 & 70 & 28 & 24 & & 1.13 & 0.89 \\
RH3 & 50 & 28 & 24 & & 1.88 & 1.48 \\
T1 & 70 & 28 & 24 & & 1.13 & 0.89 \\
T2 & 70 & 24 & 20 & & 0.89 & 0.70 \\
T3 & 70 & 20 & 16 & & 0.70 & 0.54 \\
\hline
\end{tabular}

Three relative humidity (RH) and three temperature $(T)$ treatments were used, all with $12 \mathrm{~h}$ days. Vapour pressure deficit (VPD) is given in $\mathrm{kPa}$ 
We conducted viability trials comparing new seeds with 1- and 2-year-old seeds, and these were completed immediately after the 2007 batch of seeds was collected. The older seeds were stored in room temperature conditions in Riverside, California, where average $\mathrm{RH}$ is $54 \%$. After the final seed collection date, August 2007, seeds from each year were germinated on sterile filter paper in petri dishes at a $28 / 24^{\circ} \mathrm{C}$ day/night temperature regime with $70 \% \mathrm{RH}$. Twenty dishes of each age were germinated, with ten seeds per dish. For all of the growth chamber trials, chambers were illuminated with three high pressure sodium discharge lamps (360 W each) and three metal halide lamps ( $400 \mathrm{~W}$ each). All seeds were sprayed daily with deionized water.

\section{Seed field trial}

In August 2006, A. bracteata seeds were introduced and monitored in different forest stands throughout the reserve. Mature A. bracteata plants found throughout the reserve were naturally dispersing fruits at the onset of this experiment. We used the five forest types described above: mature forest and tintal wetlands (both $>100$ years old), and three different secondary forests, within $5 \mathrm{~km}$ of each other (SF1, SF2, and SF3). Twenty seeds of A. bracteata were attached to each of 30 trees of the same species in each forest type. The tree species used was Metopium brownei Jacq., based on the following criteria: (1) well-developed bark (not smooth or defoliating), (2) common throughout the reserve, and (3) observed to host established $A$. bracteata. However, in SF3, Lonchocarpus castilloi was used, because it was abundant, had a bark surface with a texture similar to young $M$. brownei trunks, and we were not able to locate $30 \mathrm{M}$. brownei trees in this young forest. A. bracteata plants most often establish at the forks of large branches, but they are also found on trunks and semi-vertical branches (Dejean and Olmsted 1997). In our study, for consistency, seeds were attached at 1.2-m height on the northside of the trees. $A$. bracteata seeds are approximately $4.3 \mathrm{mg}, 3.9 \mathrm{~mm}$ long, and $1.4 \mathrm{~mm}$ wide. The seeds are sticky and stuck to the trees on their own. Each tree was tagged and the seeds were monitored in June 2007, October 2007, and March 2008. Both germinated and ungerminated seeds were observed at these times. Hemispherical photographs using a fish-eye lens were taken in October 2007 in the different aged forests. Photos were taken next to each 'seed' tree and were used to characterize the light environment faced by the seeds.

Field measurements

In July 2006, Hygrochron ${ }^{\text {TM }}$ iButton sensors (Maxim Integrated Products, Inc., Sunnyvale, California, USA) were deployed throughout El Edén Ecological Reserve in order to determine whether temperature and humidity varied significantly in different aged stands of forest within the same reserve. Sensors were attached at breast height, $1.2 \mathrm{~m}$ from the ground, on the north facing side of 3-5 trees in each forest type. Hourly measurements were taken from July 2006 to March 2008. Air temperature and RH were used to calculate VPD based on the equations of Jones (1992), where:

$\mathrm{VPD}=$ saturation vapour pressure - water vapour pressure.

The saturation vapour pressure (SVP) in $\mathrm{Pa}$ was calculated from air temperature $\left(T,{ }^{\circ} \mathrm{C}\right)$ :

$\mathrm{SVP}=a[\exp (b T / c+T)]$

where $a=0.061375, b=17.502$, and $c=240.97$.

The water vapour pressure (WVP) was calculated from RH and SVP:

$\mathrm{WVP}=\mathrm{RH}(\mathrm{SVP})$.

Photosynthetically active radiation (PAR) was measured for $20 \mathrm{~min}$ in each area and averages were obtained. These measurements were all taken between 10 am and noon on a cloudless morning, in order to quantify the variation between forest types.

Analyses

Statistics were run with JMP Software (SAS Institute, Inc., Cary, North Carolina, USA). When necessary, data were arcsin transformed before analysis. Differences between growth chamber treatments were determined by analysis of variance. One-way MANOVA were used to compare treatment effects as a function of time (days to germination) (Tabachnick and Fidell 2001). Data reported are means \pm 1 SE. Canopy openness was calculated from the hemispherical photographs with Gap Light Analyzer (GLA) Software (Simon Fraser University, Burnaby, British Columbia, Canada). 


\section{Results}

Seed germination in growth chambers

Percent germination significantly varied with VPD treatment $\left(F_{3.68,6} ; P<0.05\right)$. Seeds that were germinated in the two low VPD treatments $(0.34$ and $1.01 \mathrm{kPa})$ experienced $100 \%$ germination whereas those in the highest VPD treatment $(1.68 \mathrm{kPa})$ experienced $60 \%$ germination. Almost all of the seeds at a VPD of $0.34 \mathrm{kPa}$ germinated within 5 days, whereas those at $1.68 \mathrm{kPa}$ did not begin germinating until about 10 days after the trial began (Fig. 1a).

Effects of temperature resulted in differences in percent germination, but the initial rate (first 5 days of the trial) was not significant (Fig. 1b). At the warmest temperature regime $\left(28 / 24^{\circ} \mathrm{C}\right.$ day/night), germination occurred faster and to almost $100 \%$, compared with the intermediate regime $\left(24 / 20^{\circ} \mathrm{C}\right.$ day/night) where germination was delayed 2 days and maximum rates were less than $80 \%$. Seeds in the coldest regime $\left(20 / 16^{\circ} \mathrm{C}\right.$ day/night $)$ began germinating on day 5 with the warmest seeds, but maximum rates were less than $70 \%$, representing lower absolute percentages than those in the intermediate regime.

Seed age also affected germination. Two-year-old seeds failed to germinate, $75 \%$ of 1 -year-old seeds germinated, and $100 \%$ of fresh seeds germinated (Fig. 1c). One-year-old seeds began germinating 2 days later than the fresh seeds. The amount of light did not affect seed germination. Seeds germinated equally under both levels, with maximum germination occurring 7 days after the trials began.

Seed germination in the field

Seed germination and establishment in the field was very low. Seeds failed to germinate in the tintal wetland area, SF2, and SF3. During the first observation period (June 2007), 10 months after the seeds were put out, $1 \%$ of seeds had germinated in both SF1 and the mature forest. Six seedlings were growing on 3 out of the 30 trees in SF1. In the mature forest, six seedlings were growing on five out of the 30 trees. Ungerminated seeds were observed in all the forest types, indicating the seeds had remained sticky. Three months later, September 2007, survivorship was four out of six in SF1, and five out of six in the mature forest. In March 2008, 19 months after the seeds were put out, four seedlings
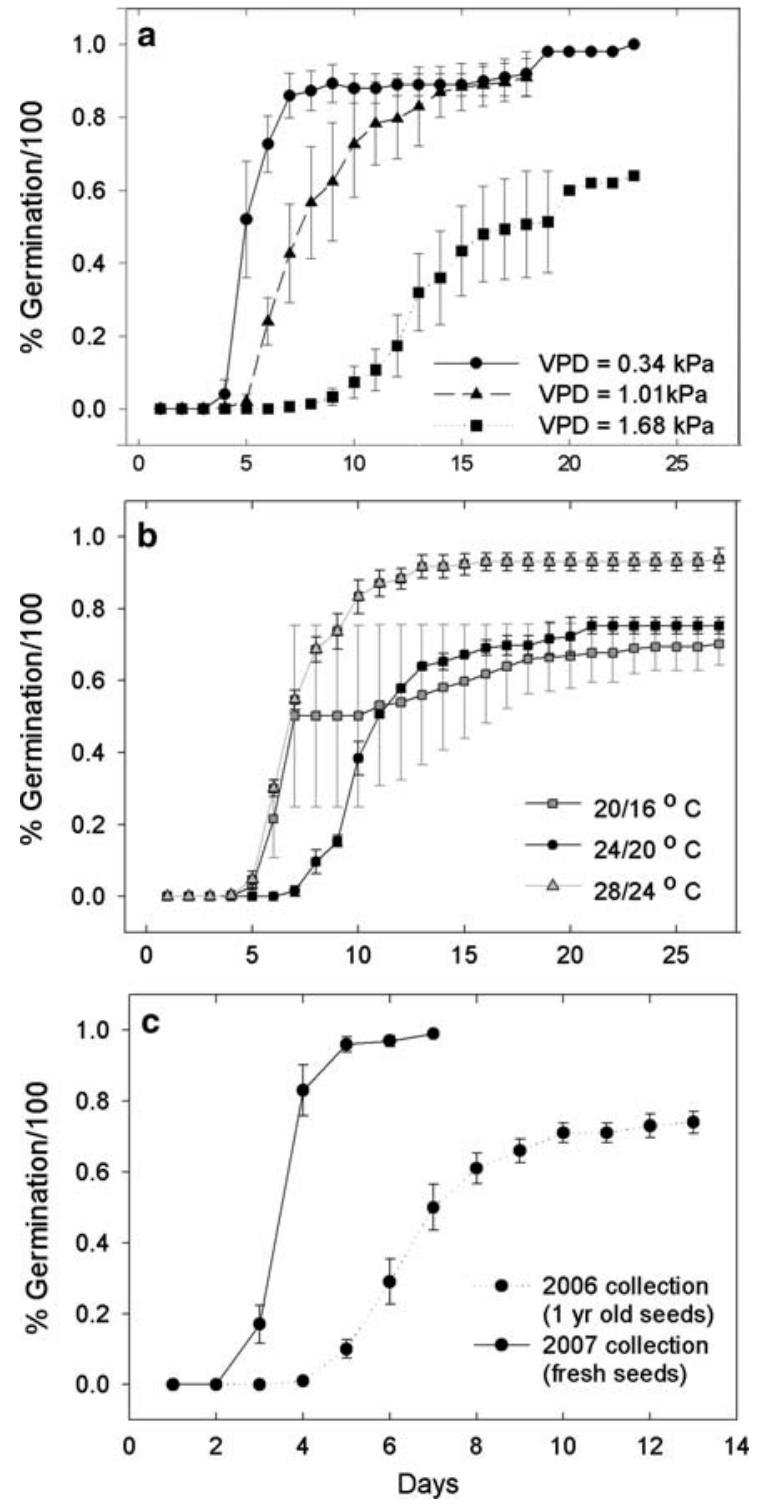

Fig. 1 Seed germination in growth chambers as a function of a vapour pressure deficit (VPD), b temperature, and c age. Temperature regime is given as day/night temperatures $\left({ }^{\circ} \mathrm{C}\right)$, with $12 \mathrm{~h}$ days. For a seeds were germinated at $28^{\circ} / 24^{\circ} \mathrm{C}$ day/ night temperatures. For b trials were run at $70 \% \mathrm{RH}$. For $\mathbf{c}$ trials were run at $28^{\circ} / 24^{\circ} \mathrm{C}$ day/night temperatures at $70 \% \mathrm{RH}$. Seeds collected in 2005 ( 2 years prior to germination trial) failed to germinate. Points represent trial means $\pm 1 \mathrm{SE}$

were alive in SF1 and three seedlings were alive in the mature forest. No differences were found between seedlings growing in the two forest types in terms of leaf number $(\mathrm{SF} 1=3.07 \pm 0.17 ; \quad \mathrm{MF}=2.86 \pm$ $0.17)$, leaf length $(\mathrm{SF} 1=1.21 \pm 0.08 \mathrm{~cm} ; \mathrm{MF}=$ 
$1.10 \pm 0.08 \mathrm{~cm})$, or growth rate $(\mathrm{SF} 1=1.90 \pm$ $0.34 \mathrm{~cm} /$ year; $\mathrm{MF}=1.44 \pm 0.30 \mathrm{~cm} /$ year). However, leaf length varied between observation events $\left(F_{4.89,2} ; P<0.01\right)$; average leaf length increased from June $(0.99 \pm 0.07 \mathrm{~cm})$ to September $2007(1.36 \pm$ $0.08 \mathrm{~cm})$, but by March 2008, length had decreased $(1.17 \pm 0.09 \mathrm{~cm})$. Number of leaves did not vary between observation dates $(3.00 \pm 0.19,3.00 \pm 0.25$, $2.89 \pm 0.22$, respectively). Within the different forest types, hemispherical photographs did not show differences in canopy openness between trees where seeds germinated versus where seeds failed to germinate.

Field conditions

Temperature, humidity, VPD, and PAR varied across the reserve based on the vegetation type. Average temperatures were higher in the tintal wetland area $\left(25.9^{\circ} \mathrm{C}\right)$ than the other forest types, and within the seral stages there were small differences (Table 2, Fig. 2). SF1 was the least warm site, averaging $23.9^{\circ} \mathrm{C}$, and $\mathrm{SF} 3$ averaged $24.0^{\circ} \mathrm{C}$. SF2 and the mature forest, both with abundant and established epiphyte populations, had slightly higher average temperatures, both at $24.6^{\circ} \mathrm{C}$. Minimum temperatures were higher in the mature forest and tintal wetland areas (both $9.6^{\circ} \mathrm{C}$ ) compared with the younger forests, which had minimum temperatures of $7^{\circ} \mathrm{C}$ or less (Table 2). Mid-day temperatures also varied: $46 \%$ of wetland temperatures between 10 am and $2 \mathrm{pm}$ were greater than $30^{\circ} \mathrm{C}, 42 \%$ of SF2 temperatures were above $30^{\circ} \mathrm{C}$, and $36 \%$ of $\mathrm{SF} 3$ temperatures were above $30^{\circ} \mathrm{C}$. SF1 and the mature forest had $31 \%$ and $32 \%$, respectively, of mid-day temperatures above $30^{\circ} \mathrm{C}$. Data for April and May of

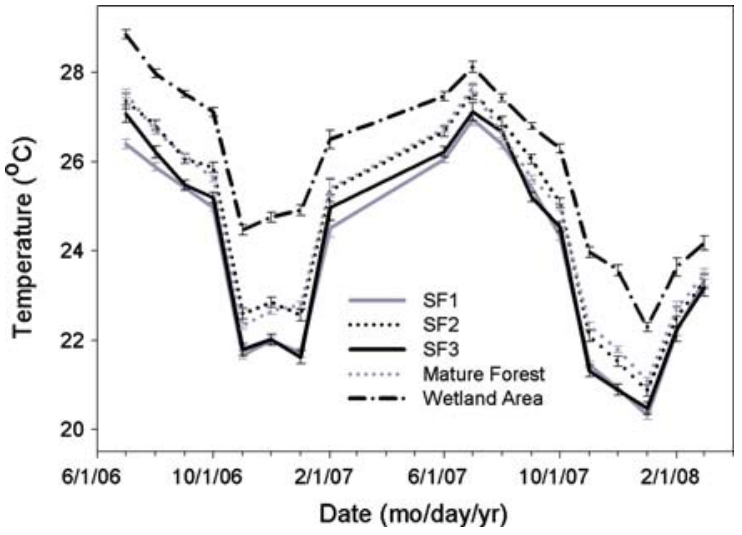

Fig. 2 Average monthly temperatures across El Edén Ecological Reserve. Data are missing for April and May 2007. Each point is an average $\pm 1 \mathrm{SE}$

2007 were missing because we were unable to download the sensors.

Average RH was about $90 \%$ in all of the forest types, except for the wetland area which had an average $\mathrm{RH}$ of $84.8 \%$ (Table 2). $\mathrm{RH}$ reached its lowest value, $15 \%$, in the wetland forest. Because VPD is a function of RH and temperature, we broke the data into daytime (7 am-7 pm) and nighttime (7 pm-7 am) sets (Fig. 3). Average VPD during the day was less than $1 \mathrm{kPa}$ for all of the forest types, but it was the lowest in SF1 and the mature forest (Table 2). Maximum daytime VPD was the lowest in SF1. Average nighttime VPD was less than $0.08 \mathrm{kPa}$ in all the forest types except the wetland area which averaged $0.16 \pm 0.01 \mathrm{kPa}$. Average daytime VPD values were significantly greater than nighttime values $(P<0.01$, Fig. 3). Maximum nighttime values were the highest in SF2, SF3, and the wetland area and the lowest in SF1

Table 2 Abiotic conditions across El Edén Ecological Reserve

\begin{tabular}{lllllllllll}
\hline $\begin{array}{l}\text { Forest } \\
\text { type }\end{array}$ & Ave $T\left({ }^{\circ} \mathrm{C}\right)$ & $\begin{array}{l}\text { Min } T \\
\left({ }^{\circ} \mathrm{C}\right)\end{array}$ & $\begin{array}{l}\text { Max } T \\
\left({ }^{\circ} \mathrm{C}\right)\end{array}$ & $\begin{array}{l}\mathrm{SD} \\
T\end{array}$ & Ave RH $(\%)$ & $\begin{array}{l}\text { Min } \\
\text { RH }(\%)\end{array}$ & $\begin{array}{l}\text { Ave VPD } \\
(\mathrm{kPa}) \text { Day }\end{array}$ & $\begin{array}{l}\text { Ave VPD } \\
(\mathrm{kPa}) \text { Night }\end{array}$ & $\begin{array}{l}\text { Max VPD } \\
(\mathrm{kPa}) \text { Day }\end{array}$ & $\begin{array}{l}\text { Max VPD } \\
(\mathrm{kPa}) \text { Night }\end{array}$ \\
\hline $\mathrm{SF3}$ & $24.01 \pm 0.05$ & 6.62 & 46.12 & 5.82 & $91.01 \pm 0.13$ & 27.00 & $0.60 \pm 0.02$ & $0.06 \pm 0.01$ & 5.01 & 4.26 \\
$\mathrm{SF} 2$ & $24.56 \pm 0.04$ & 7.08 & 50.04 & 5.52 & $89.21 \pm 0.14$ & 23.03 & $0.62 \pm 0.02$ & $0.08 \pm 0.01$ & 6.70 & 7.03 \\
$\mathrm{SF} 1$ & $23.88 \pm 0.03$ & 7.12 & 41.15 & 4.80 & $90.94 \pm 0.10$ & 32.03 & $0.43 \pm 0.01$ & $0.07 \pm 0.01$ & 3.71 & 1.90 \\
$\mathrm{MF}$ & $24.57 \pm 0.03$ & 9.64 & 47.57 & 4.45 & $90.42 \pm 0.08$ & 20.49 & $0.46 \pm 0.01$ & $0.07 \pm 0.00$ & 6.26 & 2.01 \\
$\mathrm{WA}$ & $25.88 \pm 0.03$ & 9.64 & 48.65 & 5.00 & $84.78 \pm 0.12$ & 14.99 & $0.77 \pm 0.02$ & $0.16 \pm 0.01$ & 6.71 & 5.57 \\
\hline
\end{tabular}

SF3 is the youngest secondary forest followed by SF2 and SF1 (9, 13, 19 years old, respectively). The mature forest (MF) and wetland areas (WA) are both $>100$ years old. $\mathrm{SD}=$ standard deviation. Means of temperature $(T)$, relative humidity $(\mathrm{RH})$ and vapour pressure deficit (VPD) are reported \pm 1 standard error (SE). VPD values are provided for both night and day conditions. These values are based on data collected continuously from July 2006 to March 2008, with the exception of April and May 2007 


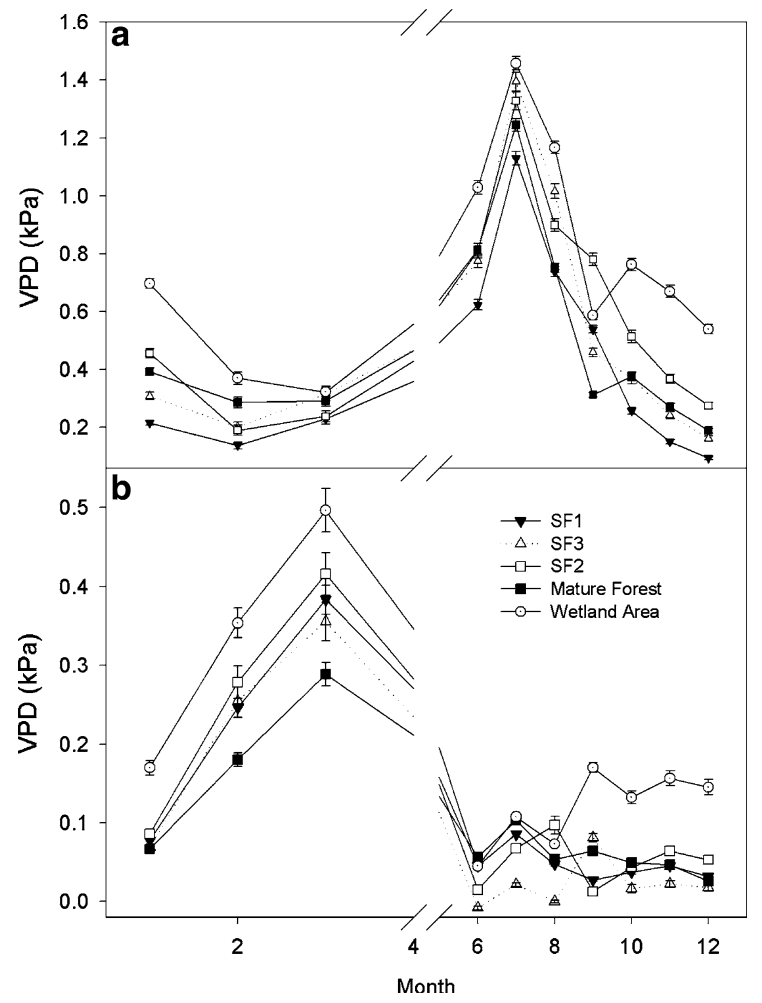

Fig. 3 Average monthly vapour pressure deficit (VPD), \pm 1 SE, across El Edén Ecological Reserve. Data are missing for April and May 2007. a Daytime averages (7 am-7 pm); b nighttime averages ( $7 \mathrm{pm}-7 \mathrm{am})$

and the mature forest (Table 2). PAR values differed among the seral stages and forest types in the reserve. The most exposed area, the tintal wetland, had average values of $950 \mu \mathrm{mol} / \mathrm{m}^{2} \mathrm{~s}$, and the mature forest averaged $177 \mu \mathrm{mol} / \mathrm{m}^{2} \mathrm{~s}$. The younger forests ranged from $146 \mu \mathrm{mol} / \mathrm{m}^{2} \mathrm{~s}$ in SF1 to $416 \mu \mathrm{mol} / \mathrm{m}^{2} \mathrm{~s}$ in SF2 to $294 \mu \mathrm{mol} / \mathrm{m}^{2} \mathrm{~s}$ in SF3. These values are from one cloudless morning only and were not intended to capture the sunflecks or diel changes.

\section{Discussion}

In the last 30 years, epiphyte establishment has been approached using seed germination trials in a range of ecosystems within Florida and throughout Mexico. Most studies found epiphyte seeds to germinate in the field at rates between 0\% and 10\% (Benzing 1978; Bernal et al. 2005; Winkler et al. 2005; Mondragon and Calvo-Irabien 2006; Toledo-Aceves and Wolf 2008). This is consistent with our observed field germination rates. Mondragon and Calvo-Irabien (2006) investigated germination of Tillandsia brachycaulos, an epiphytic bromeliad common at our field site, and reported rates comparable to ours (98\% germination in controlled conditions; $3 \%$ in the field). Winkler et al. (2005) used five epiphytic bromeliad species in field germination trials, and less than $3 \%$ of seeds survived longer than 1 year. They used 600 seeds per species, and for one species, Tillandsia multicaulis, only one seed germinated (Winkler et al. 2005). Recently, Toledo-Aceves and Wolf (2008) tried to determine the efficacy of restoring an epiphytic bromeliad, Tillandsia eizii, to oak forests in southern Mexico. They concluded that restoration efforts would be more effective if seedlings rather than seeds were put into the field. Based on the high seed germination we observed in the growth chamber and low germination in the field, efforts to restore A. bracteata may similarly have more success if seedlings rather than seeds are used. To our knowledge, no previous studies have evaluated the effectiveness of either seeds or seedlings for A. bracteata restoration.

In their field germination study, Winkler et al. (2005) reported that 524 out of 3,000 seeds had germinated within 10 weeks, but within a year more than $80 \%$ of those germinated seedlings were dead. We also placed 3,000 seeds of A. bracteata in the field. After 10 months, we only observed 12 seedlings that survived. Assuming 10\% germination and $20 \%$ seedling survival, our establishment rates resembled those of Winkler et al. (2005). One factor for increased germination observed by Winkler et al. (2005) is that the forest they used had an average temperature of $19^{\circ} \mathrm{C}$, which is $6^{\circ}$ colder than the average at our forest site. These lower temperatures could help maintain lower VPD values. In our growth chamber trials, germination of $A$. bracteata seeds was enhanced by both low VPD and high temperatures, and the relative importance of these effects is probably species specific. The low germination rates and level of seedling success that we observed in the field are likely reflective of the true recruitment rates this species experiences.

Water availability is an important factor for the epiphytic condition, because these plants have no direct contact with terrestrial soil. VPD is a measure of how close the air is to being saturated with water. In forests where the VPD is high (e.g., a forest with a less developed canopy), atmospheric water is lost rapidly 
under increased mid-day temperatures. Based on our growth chamber trials, maximum VPD levels reached in the field appear to have been too great during the year of our field experiment, especially in the tintal wetland area, SF2, and SF3. SF1 and the mature forest, the only two forest types where we observed germination under field conditions, both had fewer mid-day temperatures above $30^{\circ} \mathrm{C}$ ( $31 \%$ and $32 \%$, respectively). Average VPD was the lowest in these two forest types (SF1 = $0.43 \pm 0.01 \mathrm{kPa}$; MF $=0.46 \pm 0.01 \mathrm{kPa}$ ). Germination in the growth chambers was the highest at the lowest VPD level, but seeds did germinate at the higher levels. Within these controlled growth chamber conditions, seeds were provided with water daily, unlike the reality of conditions faced by seeds in the field, where rainfall occurred sporadically. Pulse germination is common (Chesson et al. 2004), and years with higher RH levels, (e.g., more northern frontal events), may lead to higher germination rates and increased likelihood of establishment.

Most studies use a single meteorological station to characterize the local environment. However, vegetation has an effect on these abiotic variables at small spatial scales such as the leaf boundary layer, and plants alter the microclimate of their immediate surroundings (Stuntz et al. 2002). It follows that differently statured vegetation can have contrasting abiotic conditions. In our growth chamber temperature trials, differences in germination were observed when conditions varied by as little as $4^{\circ}$. Our field observations focus on finer scale temperature differences, and the data indicate that even as few as $1-2^{\circ}$ differences in overall field temperatures may affect epiphyte germination patterns and their subsequent establishment. In contrast to the mature forest and three secondary forests, the tintal wetland area, subject to annual inundation, represents a distinct class of vegetation (Schultz 2001). The temperature data collected from the different forest types presented a few interesting patterns. The wetland air temperatures were well above the other forest types because of the openness of the terrain. SF2 and the mature forest maintained equal and relatively stable temperatures throughout the entire year. It is within these two forest areas that epiphyte communities are present. SF1 and SF3 had almost identical temperatures and were colder throughout the year than SF2 and the mature forest. In these two younger forests, established epiphyte communities do not exist. Another trend was seen in the temperature variation across the forest types. Both the standard deviations and coefficients of variation of temperature were greatest in the youngest forest and decreased throughout the aging secondary forests to a low in the mature forest. The wetland area had intermediate temperature variation. It is likely that the greater frequency of extreme temperatures in the younger forests has an inhibitory effect on young epiphytes.

Seed viability has been an understudied aspect of bromeliad biology (Benzing 2000). More than half of all 1-year-old seeds in this study germinated under growth chamber conditions, whereas none of the 2-year-old seeds germinated. In the field, seeds must land in a site suitable for germination, where they will not be subject to predation. Seeds in young and open forests may be more susceptible to predation by ants (Nepstad et al. 1996). Furthermore, RH in the field averages above $80 \%$, whereas our seeds were stored in conditions with relatively low RH. In humid tropical ecosystems, decomposition is accelerated and seed viability is probably shorter.

Previous studies have found reduced epiphyte richness and abundance in secondary compared with mature forest stands (Barthlott et al. 2001; CascanteMarín et al. 2006). Barthlott et al. (2001) looked at epiphyte diversity in mature, disturbed, and secondary forest stands (35-year-old abandoned plantations), and out of 178 species found in mature forests, only 68 were also found in either disturbed or secondary forests. They suggested that the structural complexity of mature forest vegetation makes the establishment of epiphyte communities more likely in these forest types. Interestingly, although epiphyte families overall showed decreased richness in secondary stands, Bromeliaceae richness exhibited an opposite trend (10 species in secondary forest stands compared to 7 species in mature forest stands). Barthlott et al. (2001) attributed these patterns to species-specific traits enabling particular species to tolerate increased solar radiation and decreased humidity. With regard to A. bracteata, Dejean and Olmsted's (1997) study across mature vegetation types found moderate host specificity $(35 \%$ of tree species in the area sampled were hosts; the species we used, Metopium brownei, was included), and they attributed this to bark complexity and architectural features. A. bracteata are not found on smooth barked hosts or those with defoliating bark (Dejean and Olmsted 1997). Older, well-developed bark and increased phorophyte 
richness in mature forests (Schultz 2001) increases the likelihood that epiphyte species such as $A$. bracteata will germinate and become established.

Vascular epiphytes, with access to limited supplies of water and nutrients, are generally slow growing (Zotz 1995). A. bracteata grown in our greenhouses began to flower 3 years after germination, only when supplied with fertilized water. Under field conditions, where precipitation and nutrients are supplied in pulses rather than continuously, growth is extremely slow. Seedlings growing in seasonally dry tropical forests must be able to withstand an extended dry season with little rain. Many epiphyte species release their seeds at the beginning of the wet season, and they must germinate and grow within a 4-5 months window before the onset of the dry season. Reduced rain events during this period may have a large impact on the establishment of young epiphyte seedlings (Oren et al. 1996). Our data suggest that seeds must disperse to a "safe site", that is, a site with relatively constantly low VPD, and must germinate within that first wet season, to have a chance at success. Only later-seral or mature forests provide these appropriate environments. Retaining mature forest preserves and restoring stands with late-seral architectural features will be critical for epiphyte persistence.

Acknowledgments We thank J. Castillo, R. Goode, B. Kimm, K. Kitajima, R. Lennox, E. and G. Serna, and A. Wrona for field and growth chamber assistance. We gratefully acknowledge two anonymous reviewers whose suggestions improved the manuscript. This research was supported by National Science Foundation grants EF-0410408 and DEB-0615427, and a University of California Institute for Mexico and the United States dissertation research grant.

Open Access This article is distributed under the terms of the Creative Commons Attribution Noncommercial License which permits any noncommercial use, distribution, and reproduction in any medium, provided the original author(s) and source are credited.

\section{References}

Barthlott W, Schmit-Neuerburg V, Nieder J, Engwald S (2001) Diversity and abundance of vascular epiphytes: a comparison of secondary vegetation and primary montane rain forest in the Venezuelan Andes. Plant Ecol 152:145-156. doi:10.1023/A:1011483901452

Baskin CC, Baskin JM (1998) Seeds: ecology, biogeography, and evolution of dormancy and germination. Academic Press, San Diego
Benzing DH (1978) Germination and early establishment of Tillandsia circinnata Schlecht. (Bromeliaceae) on some of its hosts and other supports in southern Florida. Selbyana 5:95-106

Benzing DH (2000) Bromeliaceae: profile of an adaptive radiation. Cambridge University Press, Cambridge

Benzing DH, Derr JA, Titus JE (1972) The water chemistry of microcosms associated with the bromeliad, Aechmea bracteata. Am Midl Nat 87:60-70. doi:10.2307/2423881

Bernal R, Teresa V, Hernández-Rosas L (2005) Habitat preference of the epiphyte Tillandsia recurvata (Bromeliaceae) in a semi-desert environment in Central Mexico. Can J Bot 83:1238-1247. doi:10.1139/b05-076

Boose ER, Foster DR, Plotkin AB, Hall B (2003) Geographical and historical variation in hurricanes across the Yucatán Peninsula. In: Gómez-Pompa A, Allen MF, Fedick SL, Jiménez-Osornio JJ (eds) The lowland Maya area. Haworth, Binghamton, pp 495-516

Cascante-Marín A, Wolf JHD, Oostermeijer JGB, den Nijs JCM, Sanahuja O, Durán-Apuy A (2006) Epiphytic bromeliad communities in secondary and mature forest in a tropical premontane area. Basic Appl Ecol 7:520-532. doi:10.1016/ j.baae.2005.10.005

Chazdon RL (2003) Tropical forest recovery: legacies of human impact and natural disturbances. Perspect Plant Ecol Evol Syst 6:51-71. doi:10.1078/1433-8319-00042

Chesson P, Gebauer RLE, Schwinning S, Huntly N, Wiegand K, Ernest MSK, Sher A, Novoplansky A, Weltzin JF (2004) Resource pulses, species interactions, and diversity maintenance in arid and semi-arid environments. Oecologia 141:236-253. doi:10.1007/s00442-004-1551-1

Dejean A, Olmsted I (1997) Ecological studies on Aechmea bracteata (Swartz) (Bromeliaceae). J Nat Hist 31:13131334. doi:10.1080/00222939700770741

Dejean A, Olmsted I, Snelling RR (1995) Tree-epiphyte-ant relationships in the low inundated forest of Sian Ka'an Biosphere Reserve, Quintana Roo, Mexico. Biotropica 27:57-70. doi:10.2307/2388903

Dejean A, Durou S, Olmsted I, Snelling RR, Orivel J (2003) Nest site selection by ants in a flooded Mexican mangrove, with special reference to the epiphytic orchid Myrmecophila christinae. J Trop Ecol 19:325-331. doi: 10.1017/S0266467403003353

Ehleringer JR, Monson RK (1993) Evolutionary and ecological aspects of photosynthetic pathway variation. Annu Rev Ecol Syst 24:411-439. doi:10.1146/annurev.es.24.110193. 002211

Galindo-Leal C, Cedeño-Vázquez JR, Calderón R, Augustine J (2003) Arboreal frogs, tank bromeliads and disturbed seasonal tropical forest. In: Contemporary herpetology number 1, 12 September 2003. Available via DIALOG. http:// www.contemporaryherpetology.org/ch/2003/1/index.htm. Accessed 14 August 2008

Gómez-Pompa A, Allen MF, Fedick SL, Jimenez-Osornio JJ (2003) The lowland Maya area. Haworth, Binghamton

Goode LK, Allen MF (2008) The impacts of Hurricane Wilma on the epiphytes of El Edén Ecological Reserve, Quintana Roo, Mexico. J Torrey Bot Soc 135:377-387. doi:10.3159/ 07-RA-052.1

Harper JL (1977) Population biology of plants. Academic Press, London 
Hietz P, Wanek W (2003) Size-dependent variation of carbon and nitrogen isotope abundances in epiphytic bromeliads. Plant Biol 5:137-142. doi:10.1055/s-2003-40730

Jones HG (1992) Plants and microclimate. Cambridge University Press, Cambridge

Lambers H, Chapin FS, Pons T (1998) Plant physiological ecology. Springer, New York

Mondragon D, Calvo-Irabien LM (2006) Seed dispersal and germination of the epiphyte Tillandsia brachycaulos (Bromeliaceae) in a tropical dry forest, Mexico. Southwest Nat 51:462-470. doi:10.1894/0038-4909(2006)51 [462:SDAGOT]2.0.CO;2

Mondragon D, Durán R, Ramírez I, Olmsted I (1999) Population dynamics of Tillandsia brachycaulos Schltdl. (Bromeliaceae) in Dzibilchaltun National Park, Yucatán. Selbyana 20:250-255

Nepstad DC, Uhl C, Pereira CA, Cardoso da Silva JM (1996) A comparative study of tree establishment in abandoned pasture and mature forest of eastern Amazonia. Oikos 76:25-39. doi:10.2307/3545745

Oren R, Zimmermann R, Terbough J (1996) Transpiration in upper Amazonia floodplain and upland forests in response to drought-breaking rains. Ecology 77:968-973. doi: $10.2307 / 2265517$

Rey PJ, Alcántara JM (2000) Recruitment dynamics of a fleshy-fruited plant (Olea europaea): connecting patterns of seed dispersal to seedling establishment. J Ecol 88:622633. doi:10.1046/j.1365-2745.2000.00472.x

Richardson BA, Richardson MJ, Scatena FN, McDowell WH (2000) Effects of nutrient availability and other elevational changes on bromeliad populations and their invertebrate communities in a humid tropical forest in Puerto Rico. J Trop Ecol 16:167-188. doi:10.1017/ S0266467400001346

Robertson K, Platt WJ (1992) Effects of fire on bromeliads in subtropical hammocks of Everglads National Park, Florida. Selbyana 13:39-49. SAS Institute Inc, Cary

Schultz GP (2001) Vegetation and floristics of the El Edén Ecological Reserve, Quintana Roo, Mexico. University of California, Riverside
Schultz GP (2003) Structure and diversity of the forests at the El Edén Ecological Reserve. In: Gómez-Pompa A, Allen MF, Fedick SL, Jiménez-Osornio JJ (eds) The lowland Maya area. Haworth, Binghamton, pp 91-114

Schultz GP (2005) Vascular flora of the El Edén Ecological Reserve, Quintana Roo, Mexico. J Torrey Bot Soc 132:311322. doi:10.3159/1095-5674(2005)132[311:VFOTEE]2.0. $\mathrm{CO} ; 2$

Schupp EW (1995) Seed-seedling conflicts, habitat choice, and patterns of plant recruitment. Am J Bot 82:399-409. doi: $10.2307 / 2445586$

Stuntz S, Simon U, Zotz G (2002) Rainforest air-conditioning: the moderating influence of epiphytes on the microclimate in tropical tree crowns. Int J Biometeorol 46:53-59. doi: 10.1007/s00484-001-0117-8

Svenning JC, Kinner DA, Stallard RF, Engelbrecht BMJ, Wright SJ (2004) Ecological determinism in plant community structure across a tropical forest landscape. Ecology 85:2526-2538. doi:10.1890/03-0396

Tabachnick BG, Fidell LS (2001) Using multivariate statistics. Allyn and Bacon, Boston

Toledo-Aceves T, Wolf JHD (2008) Germination and establishment of Tillandsia eizii (Bromeliaceae) in the canopy of an oak forest in Chiapas, Mexico. Biotropica 40:246250. doi:10.1111/j.1744-7429.2007.00344.x

Vargas R, Allen MF, Allen EB (2008) Biomass and carbon accumulation in a fire chronosequence of a seasonally dry tropical forest. Glob Chang Biol 14:109-124

Winkler M, Hulber K, Hietz P (2005) Effect of canopy position on germination and seedling survival of epiphytic bromeliads in a Mexican humid montane forest. Ann Bot (Lond) 95:1039-1047. doi:10.1093/aob/mci115

Wright SJ (2005) Tropical forests in a changing environment. Trends Ecol Evol 20:553-560. doi:10.1016/j.tree.2005. 07.009

Wright SJ, Muller-Landau HC (2006) The future of tropical forest species. Biotropica 38:287-301. doi:10.1111/ j.1744-7429.2006.00154.x

Zotz G (1995) How fast does an epiphyte grow? Selbyana 16:150-154 